5. Akhtar S, Ashgar A. 2011. Mineral fortification of whole wheat flour. In: Flour and Breads and their Fortification in Health and Disease Prevention. New York: Elsevier. p. 263-71.

6. Manthey, F.A., Schorno, A.L., 2002. Physical and cooking quality of spaghetti madefrom whole wheat durum. Cereal Chem. 79. p.504-510.

7. Yurchak V.G. Researchofmacaronipropertiesofwholewheatflour / VG Yurchak, G.V. Karpyk, T.P. Golikova // ScientificpapersoftheNationalUniversityofFood Technologies - 2012.- No. 47. - p.123-128.

8. GOST 27669-88 "Wheat flour baking. Method of trial laboratory bread baking ". M.: 1988. - 9 p.

9. GSTU 46.004-99. "Flouriswheat. Specifications". - Kyiv, 1999. - 9 p.

Надійшла 28.08.2018. До друку 12.09.2018. Рецензія 29.08.2018

Адреса для переписки:

ОНАХТ, вул. Канатна, 112, м. Одеса, 65039

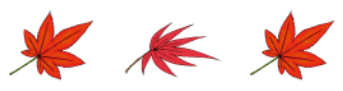

УДК 664.64.016.8:338.33:338.439.5

Н.Ю. СОКОЛОВА, канд. техн. наук, ст. викладач, О.М. КОТУЗАКИ, канд. техн. наук,

ст. викладач, Л.Г. ПОЖИТКОВА, канд. техн. наук, асистент

Одеська національна академія харчових технологій, м. Одеса

\title{
АНАЛІЗ ПРОБЛЕМ ХЛІБОПЕКАРСЬКОЇ ГАЛУЗІ, СТАН РИНКУ ТА АКТУАЛЬНІ ШЛЯХИ РОЗШИРЕННЯ АСОРТИМЕНТУ
}

Анотація

Хлібопекарська промисловість України має велике сочіальне значення, вона є підтримкою стабільності у суспільстві, а підприємства, щзо виробляють такий значимий для кожного пересічного україния продукт харчування, як хліб, прагнуть задовольнити потреби усіх верств населення. Тим не менш, не дивлячись на таку значимість, останнім часом у галузі спостерігаються негативні прочеси, що істотно впливають не лише на якість виробів, а й на загальні тендениії у виробництві та реалізації продукиії. В даній статті проаналізовано основні проблеми хлібопекарської промисловості, розглянуто стан ринку хлібобулочних виробів у иььому аспекті та запропоновано актуальні шляхи розширення асортименту. Вибір напрямів впровадження інноваційних засад має трунтуватися на індивідуальних потребам кожного окремо взятого виробництва і бути начіленим на конкретну групу споживачів. Саме такий підхід має забезпечити гарантований результат.

Останнє десятиліття ичіла група хлібобулочних виробів, залишається поза увагою великих підприємств та науковців, розроблені за останні роки основні конщептуальні підходи до розвитку нових технологій хлібобулочних виробів рідко стосуються сухарних виробів. Тим не менш, їх можна розглядати як перспективну групу хлібобулочних виробів, щуо за рахунок оптимізація параметрів тістоприготування, складу харчових добавок багатофункціонального дї дасть можливість отримати додатковий прибуток, оскільки їх вартість значно відрізняється від вартості сочіально значимого хліба, окрім того строки реалізачії хлібобулочних виробів пониженої вологості дають можливість розглядати їх навіть як групу виробів, щчо можуть імпортуватися.

Створення нових технологій сухарних виробів поліпшеної якості на основі регулювання біотехнологічних процесів виробництва дозволить розиирити асортимент та популяризувати цей продукт харчування. Модернізація існуючих шляхів удосконалення якості хлібобулочних виробів пониженої вологості, які включають як використання поліпшувачів різної природи, так $і$ застосування технологічних прийомів та рішень дозволить перевести такі вироби у площину дієтичного та спеціального призначення. Оскільки в світлі останніх досягнень в області науки про харчування пріоритетним є створення асортименту виробів пониженої вологості для дієтичного та спеціального харчування.

Ключові слова: ринок хлібобулочних виробів Украӥни, хлібобулочні вироби пониженої вологості, технологічні рішення, якість.

Хлібопекарська промисловість України посідає в системі АПК одне з провідних місць, тому що виконує завдання $з$ виробництва для населення традиційно важливої продукції першої необхідності, яка відрізняється широким асортиментом. У загальному обсязі валової продукції харчової промисловості частка хлібопекарської промисловості становить понад 15\%; питома вага iї виробничих основних фондів в основних фондах харчової промисловості - 8\% [1, 2].

За даними дослідницької компанії GfK Ukraine, споживання хліба в Україні кожного року падає $\mathrm{i}$ спостерігається така тенденція з 2008 року, особливо за рахунок продукції, що відноситься до низького цінового сегмента. Сьогодні ринок хліба та хлібобулочних виробів значно різниться як за асортиментом так і за виробниками. Згідно даних маркетингових досліджень компанії «Maxrise consulting» основними гравцями ринку $є$ : «Київхліб», «Хлібні інвестиції», «Кулінічі», «Група Лауффер», «Формула смаку», «Концерн Хлібпром» та інші. Сумарна доля інших виробників складає 48,1\% [3]. Узагальнивши всі проблеми, які на сьогодні постають перед виробниками хлібопекарської продукції, можна резюмувати, що в основному зниження рівня виробництва хлібобулочних виробів в Україні протягом останнього десятиліття було зумовлено рядом факторів $[4,5]$. 


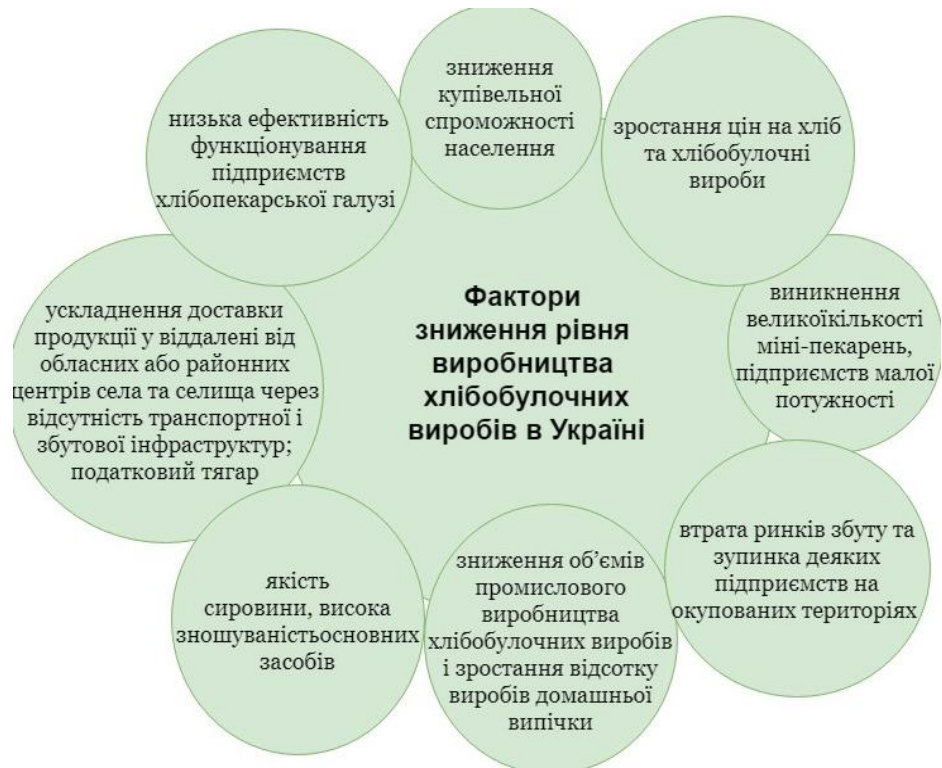

Рис. 1 - Основні фактори зниження рівня виробництва хлібобулочних виробів в Украӥні

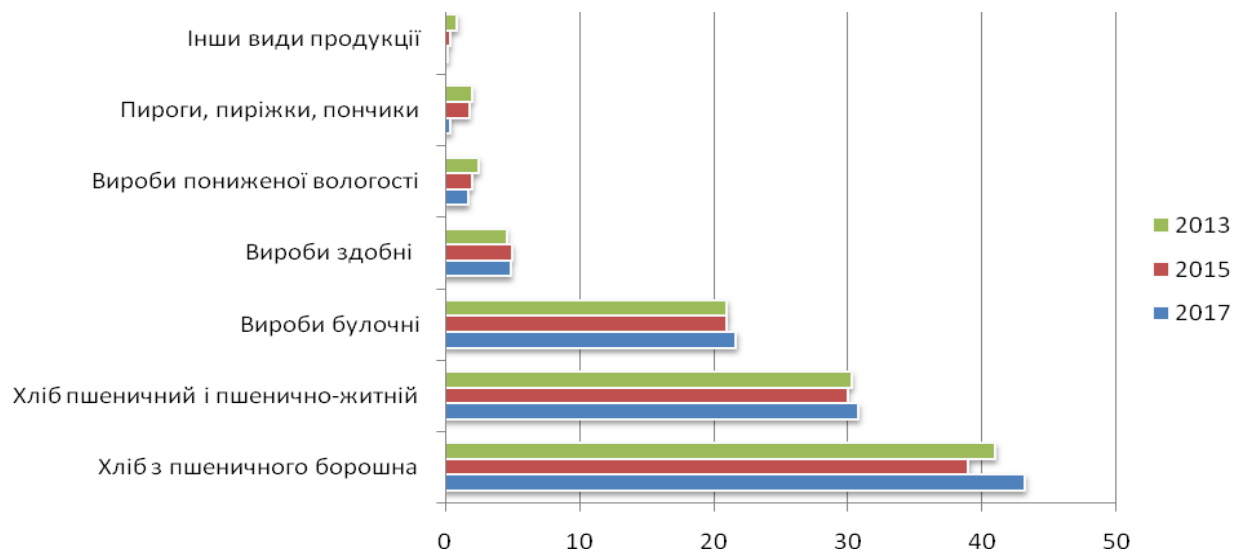

Рис. 2 - Структура ринку хлібобулочних виробів за групами період 2013-2017 рр.
Окрім того, для хлібопекарської промисловості характерна висока транспортабельність основної сировини (борошна) при цьому невисока транспортабельність готової продукції. 3 огляду на це строки зберігання основної частини вробленої продукції, не перевищує термін в 72 години. Ситуація ускладнюється умовами роботи, що відповідає до щоденного (мінливого за величиною і асортиментом) замовлення посередників. В масштабах підприємств великої потужності реагувати на всі різкі зміни в асортименті і потребах споживачів безумовно складно [6].

Якщо узагальнити дані щодо структури ринку хлібобулочних виробів за асортиментом, які були представлені Державним центром статистики України, аналітичної компанії «AR-Group» та компанії ProConsulting [7-9] у період 2013-2017 pp., що представлені на рис. 2, стане очевидним зменшення частки хліба та постійного збільшення частки іншої продукції, категорії пироги, пиріжки, пончики та вироби пониженої вологості.

Така ситуація склалася через низку причин, виробники починають розуміти, що для ефективного функціонування і сталого розвитку підприємств як великої, так і малої потужності в скрадних економічних умовах в даний час $\epsilon$ складною

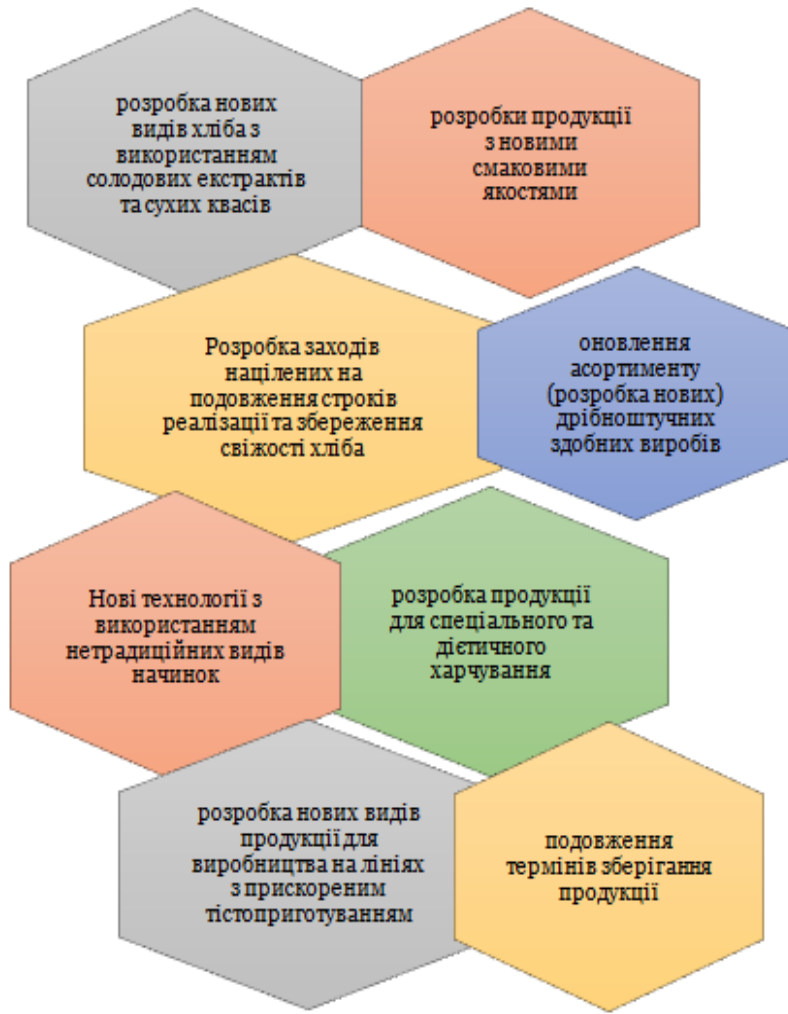

Рис. 3 - Основні напрямки розширення асортименту комплексною проблемою. В першу чергу, це стосується таких іiі сторін, як менеджмент і маркетинг. Сьогодні до хлібобулочних виробів висуваються нові вимоги, вони мають не просто доступним продуктом харчування, що швидко втамовує голод, а ще й бути такими, які виділяли б їх, оскільки конкуренція в цій групі товарів досить висока. Саме тому проблема просування товару стає все більш актуальною, адже все більше виробників розуміють, що фізичні характеристики товару, у випадку коли ринок насичений пропозицією, впливають не достатньо на вибір споживача.

Зважаючи на факт, що все більше споживачів прагнуть дотримуватись здорового способу життя i ведуть боротьбу із зайвою вагою, зростає популярність інноваційних продуктів - хліба дієтичного та лікувально-профілактичного спрямування, що містять зернові суміші, висівки, фруктозу, мед, горіхи, овочеві і фруктові добавки. Отже, на таку частку продукції припадає близько 5-7 \% від загального обсягу продажів. Однак, за даними маркетологів, потреба населення в групі дієтичних хлібобулочних виробів, збагачених вітамінами, буде рости. кам, що займаються випуском хлібобулочних виробів 3 різноманітними функціональними добавками.
Такі тенденції дають певні переваги виробни- 


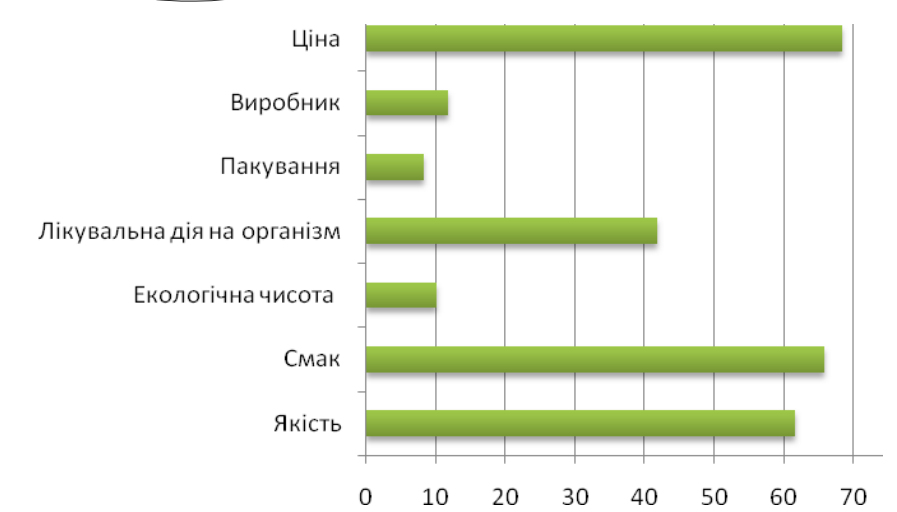

Рис. 4 - Основні фактори, щио впливають на вибір споживачів при купівлі профілактичного $i$ лікувального харчування

Таким чином, незважаючи на те що, згідно із статистичною інформацією, ринок хліба і хлібобулочних виробів скорочується в натуральному вираженні, він продовжує зростати за рахунок попиту на більш дорогі та якісні продукти.

Для успішного ведення сучасного бізнесу на хлібопекарському ринку підприємства змушені розширювати асортиментний ряд і проводити модернізацію виробництва.

Наразі асортимент хліба та хлібобулочних виробів, що випускається заводами в Україні, налічує майже 1000 найменувань і щороку до них додається ще кілька десятків. Виробники розширюють його за рахунок не скільки використання нових технологій, скільки застосуванням добавок (кунжут, льон, родзинки, спеції, горіхи, кокосова стружка тощо), наповнювачів

Загальновідомим є факт, що виробництво соціальних сортів хліба $є$ низькорентабельним, а даний вид товарної категорії займає близько 80\% загального обсягу виробництва хліба в Україні, суттєво випереджаючи преміальні й функціональні сорти хліба $5 \%$ і $3 \%$ відповідно

3 кожним роком споживання хлібобулочних виробів з групи профілактичного і дієтичного призначення в багатьох країнах світу стрімко зростає, при цьому виробництво масових сортів хліба знижується.
Ця тенденція чітко просліджується на ринках США та деяких країн СС. Беручи за приклад Францію можна відзначити, що загальне споживання хліба знизилось до 170 г на добу на одну людину, що в перерахунку становить 3,3 млн. тонн на рік. В той же час споживання хлібобулочних виробів 3 підвищеним вмістом білка, зниженим вмістом натрію, виробів 3 фортифікованого борошна, 3 додаванням нетрадиційної для хлібопечення рослинної сировини зроста. При цьому соціологічні опитування показують, що основними критеріями при виборі для покупців залишаються ціна та смак (рис. 4) [10, 11].

Сухарні вироби займають особливе місце серед хлібобулочних виробів, завдяки своїм смаковим i поживним властивостям. Сухарі висококалорійні, містять багато легкозасвоюваних вуглеводів, є своєрідними хлібними консервами, які можна зберігати тривалий час і перевозити на далекі відстань, користуються постійним попитом населення.

Як відзначають аналітики компанії ProConsulting, на ринок хлібобулочних виробів, в т.ч. сухарів впливає безліч факторів. Нинішній стан економічної і політичної ситуації в Україні не сприяє активному розвитку бізнесу. Нестабільність і конкурентний тиск з боку товарів замінників призведе до того, що ринок сухарних виробів буде стагнувати [11]. Незважаючи на загальні негативні тенденції в розвитку галузі хліба і хлібобулочних виробів, в період з 2010 року галузь виробництво сухарних виробів характеризується зростанням. Якщо в 2010 році українськими підприємствами було вироблено 50,8 тис. тонн, то в 2013 році - 52,4 тис. тонн [2,3,5]. Така ситуація також пояснюється розширенням асортиментного пропозиції продукції на ринку, що створює додатковий попит.

У той же час експерти Об'єднання «Укрхлібпром» зазначають, що рівень насиченості ринку ХБВ в Україні становить всього 45-50\%, що говорить про великий нереалізований потенціал галузі, в т.ч. і сегмента сухарів. Основну частку ринку сухарів в Україні займає вітчизняна продукція, тим не менш питома вага імпортної продукції поступово збільшується. В даному сегменті ринку в Україні працює до десяти

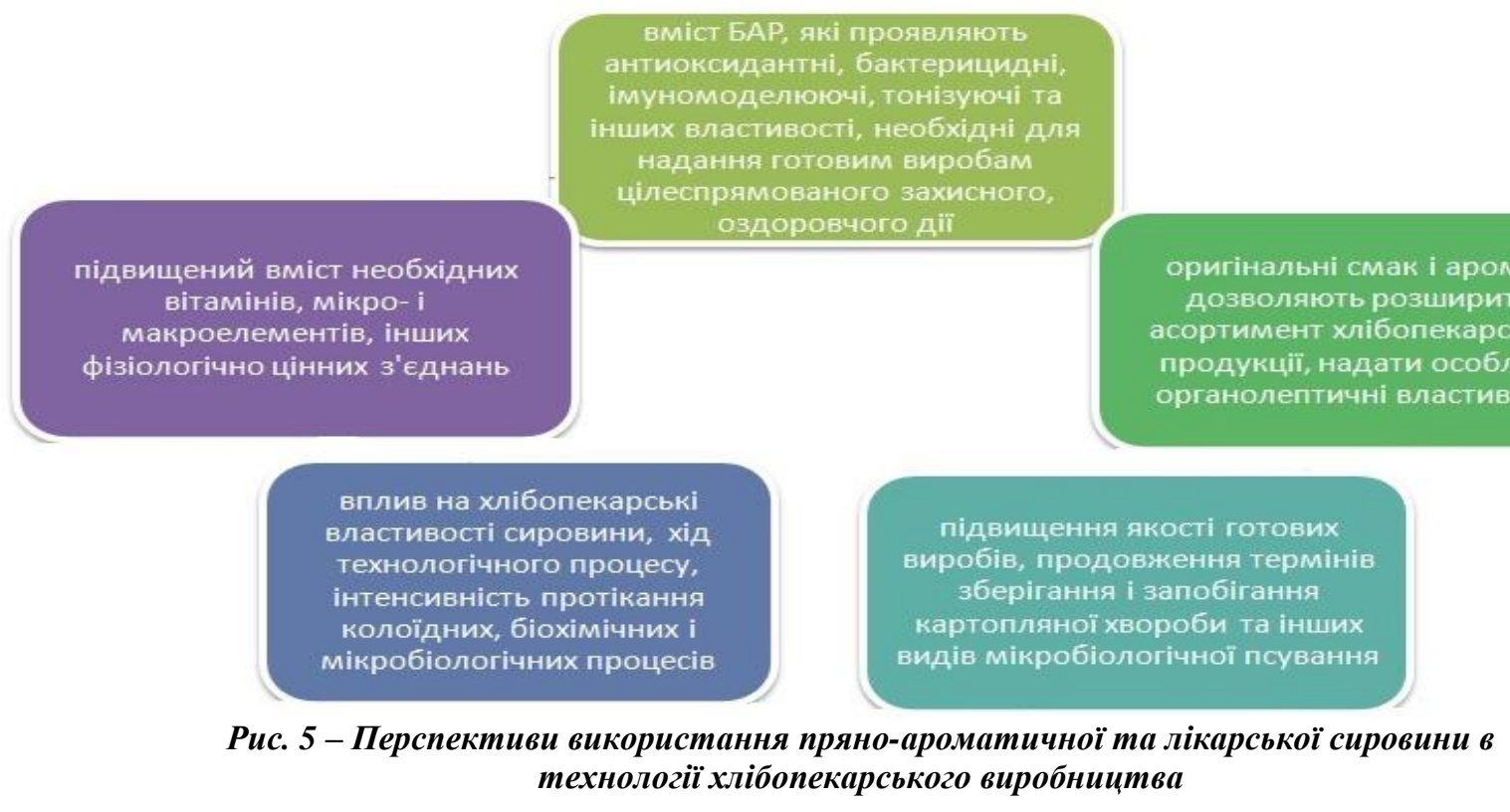


гравців, серед яких п'ятірка лідерів за підсумком останніх п'яти років зайняла 99,95 \% загального обсягу виробництва. Це такі торгові марки, як «Флінт», «Клинское», «Оболонські» і «Хрускіт». Серед інших гравців відзначимо ТОВ «Захід ТМ» (ТМ «Аміго»), ПрАТ «Шполянський завод продтоварів (ТМ« Жайвір»), ТОВ Фірма «Лотос» (ТМ« WEST ХРУСКІТ»).

У зв'язку із зростанням собівартості виробництва сухарних виробів кожен рік відзначається збільшенням їх відпускної оптової ціни по всіх категоріях. Найбільші обсяги ринку здобних сухарів відзначаються в Київській (разом з м Київ), Запорізької, Донецької та Дніпропетровської областях. Ця тенденція пов'язана 3 концентрацією найбільших виробників саме в цих регіонах. Лідируюче місце в рейтингу обсягу ринку снекових сухарів в розрізі регіонів України займає Дніпропетровська область, в якій розташовані виробничі потужності великого виробника - ТОВ «Фактор» (ТМ «Флінт»).

Якщо проаналізувати склад хлібобулочних виробів на вміст синтетичних добавок, то, напевно, першість буде за сухарними виробами. Для їх приготування використовують підсилювачі смаку, стабілізатори, консерванти, речовини, що попереджують злежування, та ін. Крім того, виробники зустрічаються 3 проблемою зберігання таких виробів, оскільки в їх рецептуру входить велика кількість рослинних жирів, розвиток окислювальних процесів в яких призводить до появи сполук перекисного характеру, карбонільних з'єднань (альдегідів, кетонів), низькомолекулярних кислот, оксикислот і т.д. В результаті сухарні вироби набувають неприємних смаку та аромату, втрачають свою харчову цінність, накопичують токсичні речовини та продукти життєдіяльності мікроорганізмів, що робить їх небезпечними для здоров'я людини.

Крім інновацій в апаратурному оснащенні істотні зміни відбулися і в рецептурному складі. 3 метою стабілізації якості сухарних виробів під час виробництва та зберігання, запобігання окислювально- го псування жирів, мікробіологічного псування, мінімізації повернень і втрат грошових вкладень виробники все частіше змушені звертатися до поліпшувачі синтетичної природи. Поліпшувачі часто мультикомпонентних і включають емульгатори, ферменти, модифікований крохмаль, метанова, бензойну кислоти, аскорбінову кислоти і їі солі [10]. Однак поширення використання харчових добавок при виробництві сухариків пов'язано не тільки 3 дешевизною і простотою, але й через відсутність альтернативи. Тому пряно-ароматичні та лікарські рослини, які поєднують в собі високу фізіологічну цінність, що дозволяе надати готовим виробам цілеспрямований вплив на організм людини, оригінальні смакові i ароматичні властивості, а також простота внесення в продукт роблять їх цікавими і затребуваними для харчової промисловості в цілому, і хлібопекарської промисловості зокрема. Крім того, водні екстракти даних рослин, за літературними даними, містять значну кількість БАР в доступній засвоюваній формі.

Якщо розглядати дані екстракти в якості сировини для хлібопекарського виробництва, то важливо також враховувати вплив комплексу БАР на стан мікрофлори тіста, хід технологічного процесу і якість готових виробів з точки зору інтенсифікації приготування тіста і скорочення тривалості технологічного циклу при збереженні високої якості готових виробів [12]. 3 огляду на суттєві відмінності в хімічному складі лікарських і пряно-ароматичних рослин можна розглядати можливість нівелювання відхилень і коливань в хлібопекарських властивостях борошна, що надходить на хлібозаводи і пекарні. А їх бактерицидні властивості можна використовувати для додаткового контролю мікрофлори хлібопекарських напівфабрикатів, забезпечення мікробіологічної безпеки і запобігання картопляної хвороби, пліснявіння хліба та інших видів мікробіологічної псування, що є серйозною проблемою для підприємств галузі в даний час.

\section{ЛІТЕРАТУРА}

1. Анализ рынка хлеба и хлебобулочных изделий в Украине [Електронний ресурс] // InVenture Investment Group - Pежим досmyny do pecypcy: https://inventure.com.ua/analytics/investments/analiz_rynka_hleba_i_hlebobulochnyh_izdelij_v_ukraine.

2. Рынок хлебобулочных изделий Украины: обзор 2016 года [Електронний ресурс] // РБК-Украина. Исследования рынков. 2016. - Режим доступу до ресурсу: http://marketing.rbc.ua/news/23.11.2016/8507.

3. Навольская Н. В. Исследование рынка хлеба и хлебобулочных изделий Украины [Електронний ресурс] / Н. В. Навольская Режим доступу до ресурсу: https://maxrise-consulting.com/analiz-rynka-hleba/.

4. Навольська Н.В. Дослідження ринку хліба і хлібобулочних виробів в украӥні / Н. В. Навольська. // Глобальні та національні проблеми економіки. - 2016. - №11. - С. 438-441.

5. Бергер В.В. Дослідження ринку хлібопекарної та кондитерської галузей украӥни / В. В. Бергер. // Вісник соиіальноекономічних досліджень. - 2017. - №1. - С. 64-70.

6. Литвиненко Г. ХЛЕБНОЕ МЕСТО [Електронний ресурс] / Галина Литвиненко // Бизнес-публикачии. - 2015. - Режим досmyny до pecypcy: https://msb.aval.ua/ru/news/?id=25834.

7. Державна служба статистики [Електронний ресурс] - Режим доступу до ресурсу: http://www.ukrstat.gov.ua/

8. Васіна К. Загальна характеристика ринку хліба та хлібопродуктів Украӥни. [Електронний ресурс] — Режим доступу до pecypcy: http://www.credit-rating.ua/ua/analytics/analytical-articles/12894/.

9. Костецька Н.I. Ринок хліба і хлібобулочних виробів Украӥни: стан і перспективи розвитку / Н.I. Костецька // Галицький економічний вісник. - 2015. - Т. 48. - № 1. - С. 26-31.

10. Сирохман, І.В. Якість і безпечність зерноборошняних продуктів. Навчальний посібник [Текст]/ I.В. Сирохман, Т.М. Лозова-К.: Центр навчальної літератури, 2006. - 384 c.

11. Рынок хлебобулочных изделий Украины [Електронний ресурс] //Исследования рынков - 2018. - Режим доступу до ресурсу https://pro-consulting.ua/

12. Лебеденко, Т.Е. Новые источники биологически активных компонентов для производства хлеба [Текст] / Т.Е. Лебеденко, Т.П. Новичкова, Н.Ю. Соколова [и др.]// Зернові продукти і комбікорми. - 2011. - № 3(43). - C.23-28.

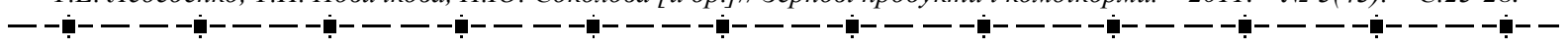




\title{
N. SOKOLOVA, PhD, senior lecture, PhD, O. KOTUZAKY, senior lecture,
}

L. POZHITKOVA, PhD, assistant Professor

Odessa National Academy of Food Technologies

\section{ANALYSIS OF THE PROBLEMS IN THE BAKERY INDUSTRY, THE STATE OF THE MARKET AND ACTUAL WAYS OF ITS DIVERSIFICATION}

\begin{abstract}
The bakery industry of Ukraine has a significant social importance, it is the support of stability in society, and enterprises producing such a significant food for every average Ukrainian as a bread, aspire to satisfy the needs of all parts of the population. Nevertheless, in spite of this importance, in recent years in the industry, there are negative processes that significantly affect not only the quality of products but also the general trends in production and sales. In this article the main problems of the baking industry are analyzed, the state of the bakery market in this aspect is considered and the actual ways of expansion of the assortment are offered. The choice of directions for the implementation of innovative principles should be based on the individual needs of each individual production and be aimed at a specific group of consumers. This approach should ensure a guaranteed result.

Over the past decade, a whole group of bakery products left out by the attention of large enterprises and scientists, developed in recent years, the basic conceptual approaches to the development of new technologies bakery products rarely apply to bakery products with low moisture content. Nevertheless, they can be considered as a up-andcoming group of bakery products, which, due to optimization of dough preparation parameters, the composition of nutritional supplements of multifunctional action will give an opportunity to get additional profit, as their value differs significantly from the value of socially significant bread, besides the terms of sale of baked goods with low moisture content give an opportunity to consider them even as a group of products that can be imported.

Creation of new technologies of improved quality based on the regulation of biotechnological production processes will expand the range and popularize this food product. Modernization of existing ways to improve the quality of low-moisture bakery products, which include both the use of improvers of different nature and the use of technological receptions and solutions, will allow the transfer of such products to the dietary and special-purpose level. Since in the light of recent advances in nutrition science, the creation of a range of low humidity products for diet and special nutrition is a priority.
\end{abstract}

Key words: bakery market of Ukraine, low-moisture bakery products, technological solutions, quality.

\section{REFERENCES}

1. Analiz rynka hleba i hlebobulochnyh izdelij v Ukraine [Elektronnij resurs] // InVenture Investment Group - Rezhim dostupu do resursu: https://inventure.com.ua/analytics/investments/analiz_rynka_hleba_i_hlebobulochnyh_izdelij_v_ukraine.

2. Rynok hlebobulochnyh izdelij Ukrainy: obzor 2016 goda [Elektronnij resurs] // RBK-Ukraina. Issledovanija rynkov. 2016. - Rezhim dostupu do resursu: http://marketing.rbc.ua/news/23.11.2016/8507.

3. Navol'skaja N. V. Issledovanie rynka hleba i hlebobulochnyh izdelij Ukrainy [Elektronnij resurs] / N. V. Navol'skaja Rezhim dostupu do resursu: https://maxrise-consulting.com/analiz-rynka-hleba/.

5. Navol`s`ka N. V. DOSLIDZhENNYa RY`NKU XLIBA I XLIBOBULOChNY`X VY`ROBIV V UKRAYiNI / N. V. Navol`s`ka. // Global`ni ta nacional 'ni problemy`ekonomiky`. 2016. - \#11. - S. 438-441.

6. Berger V. V. DOSLIDZhENNYa RY'NKU XLIBOPEKARNOYi TA KONDY'TERS KOYi GALUZEJ UKRAYINY / V. V. Berger. // Visny`k social`no-ekonomichny`x doslidzhen`. -2017. - \#1. - S. 64-70.

7. Litvinenko G. HLEBNOE MESTO [Elektronnij resurs] / Galina Litvinenko // Biznes-publikacii. - 2015. - Rezhim dostupu do resursu: https://msb.aval.ua/ru/news/?id=25834.

8. Derzhavna sluzhba staty`sty`ky`[Elektronny`j resurs] - Rezhy`m dostupu do resursu: http://www.ukrstat.gov.ua/

9. Vasina K. Zagal`na xaraktery`sty`ka ry`nku xliba ta xliboproduktiv Ukrayiny`. [Elektronny`j resurs] — Rezhy`m dostupu do resursu: http://www.credit-rating.ua/ua/analytics/analytical-articles/12894/.

10. Kostecz`ka N.I. Ry`nok xliba i xlibobulochny`x vy`robiv Ukrayiny`: stan i perspekty`vy` rozvy`tku / N.I. Kostecz`ka // Galy`cz'ky`j ekonomichny`j visny`k. - 2015. - T. 48. - \# 1. - S. 26-31.

11. Sy`roxman, I.V. Yakist` $i$ bezpechnist` zernoboroshnyany`x produktiv. Navchal`ny`j posibny`k [Tekst]/I.V. Sy`roxman, T.M. Lozova - K.: Centr navchal'noyi literatury', 2006. - 384 s.

12. Rynok hlebobulochnyh izdelij Ukrainy [Elektronnij resurs] //Issledovanija rynkov - 2018. - Rezhim dostupu do resursu https://pro-consulting.ua/

13. Lebedenko, T.E. Novye istochniki biologicheski aktivnyh komponentov dlja proizvodstva hleba [Tekst] / T.E. Lebedenko, T.P. Novichkova, N.Ju. Sokolova [i dr.] // Zernovi produkti i kombikormi. - 2011. - № 3(43). - S.23-28.

Надійшла 28.08.2018. До друку 14.09.2018. Рецензія 10.09.2018 